\title{
Characterization of a New Monopartite Begomovirus with a Betasatellite Associated with Leaf Curl, Yellow Vein, and Vein Enation in Hibiscus rosa-sinensis
}

\author{
Chih-Hung Huang, ${ }^{1,2}$ Chia-Hsing Tai, ${ }^{2}$ Nabin Sharma, ${ }^{2}$ Chia-Hung Chao, ${ }^{3}$ Chung-Jan Chang, ${ }^{4}$ and Fuh-Jyh Jan ${ }^{1,2,5, \dagger}$ \\ ${ }^{1}$ Ph.D. Program in Microbial Genomics, National Chung Hsing University and Academia Sinica, Taichung 40227, Taiwan \\ ${ }^{2}$ Department of Plant Pathology, National Chung Hsing University, Taichung 40227, Taiwan \\ ${ }^{3}$ Plant Protection Laboratory, Taichung District Agricultural Research and Extension Station, Changhua 51544, Taiwan \\ ${ }^{4}$ Department of Plant Pathology, University of Georgia, Griffin 30223, U.S.A. \\ ${ }^{5}$ Advanced Plant Biotechnology Center, National Chung Hsing University, Taichung 40227, Taiwan
}

\begin{abstract}
A new begomovirus, tentatively named hibiscus yellow vein leaf curl virus (HYVLCV), was identified in Hibiscus rosa-sinensis plants showing symptoms of leaf curl, yellow vein, and vein enation on the undersides of the leaf in Taiwan. Sequence analysis of the full-length HYVLCV genome from the rolling cycle amplicon revealed a genome of 2,740 nucleotides that contains six open reading frames and a conserved sequence (5'-TAATATTAC-3') commonly found in geminiviral genomes. HYVLCV shares the highest nucleotide identity $(88.8 \%)$ with cotton leaf curl Multan virus (CLCuMuV) genome, which is lower than the criteria $(91 \%)$ set for species demarcation in the genus Begomovirus. No begomoviral DNA-B was detected; however, a begomovirus-associated DNA betasatellite (DNA- $\beta$ ) was detected. The

demarcation threshold for a distinct DNA- $\beta$ species, the DNA- $\beta$ of HYVLCV reported in this study is considered the same species of MaYVB and tentatively named MaYVB-Hib. An expected 1,498-bp fragment was amplified with two HYVLCV-specific primers from 10 of 11 field-collected samples. Four independent amplicons were sequenced, revealing $100 \%$ nucleotide identity with the HYVLCV genome. Agroinoculation of a dimer of the infectious monopartite genome alone to Nicotiana benthamiana resulted in mild symptoms at 28 days postinoculation (dpi); coagroinoculation with the DNA- $\beta$ satellite resulted in severe symptoms at $12 \mathrm{dpi}$. HYVLCV could be transmitted to healthy $H$. rosa-sinensis by grafting, resulting in yellow vein symptoms at $30 \mathrm{dpi}$.
\end{abstract} DNA- $\beta$ (1,355 nucleotides) shares the highest nucleotide identity (78.6\%) with malvastrum yellow vein betasatellite (MaYVB). Because the identity is slightly higher than the criteria (78\%) set for the species
Keywords: begomovirus, enation, Hibiscus rosa-sinensis, leaf curl, new virus, yellow vein
Hibiscus rosa-sinensis L., also known as Chinese hibiscus, is a popular malvaceous ornamental shrub commonly planted in the tropics and subtropics. H. rosa-sinensis is also known to have aesthetic and medicinal values (Ross 2003). Several RNA viruses have been reported to infect $H$. rosa-sinensis. These include hibiscus chlorotic ringspot virus (HCRSV) (genus Carmovirus) (Waterworth 1976), hibiscus latent ringspot virus (HLRSV) (genus Nepovirus) (Brunt et al. 1980), eggplant mottled dwarf virus (genus Nucleorhabdovirus) (De Stradis et al. 2008), okra mosaic virus (genus Tymovirus) (Stephan et al. 2008), and three viruses in the genus Tobamovirues, including tomato mosaic virus (Huang et al. 2004), hibiscus latent Singapore virus (HLSV) (Srinivasan and Wong 2006; Srinivasan et al. 2002), and hibiscus latent Fort Pierce virus (HLFPV) (Adkins et al. 2003, 2006).

Two DNA viruses, cotton leaf curl Multan virus (CLCuMuV), first reported in India, and cotton leaf curl Kokhran virus-Burewala

\footnotetext{
${ }^{\dagger}$ Corresponding author: F.-J. Jan; fjjan@nchu.edu.tw

C.-H. Huang and C.-H. Tai contributed equally to this work.
}

Funding: This work was partially supported by grants from the Ministry of Science and Technology, Taiwan (105-2313-B-005-019-MY3) and by the Advanced Plant Biotechnology Center from The Featured Areas Research Center Program within the framework of the Higher Education Sprout Project by the Ministry of Education (MOE), Taiwan.

The author(s) declare no conflict of interest.

Accepted for publication 31 December 2019.

(C) 2020 The American Phytopathological Society
(CLCuKoV-Bu, formerly cotton leaf curl Burewala virus), first reported in Pakistan (both belonging to the genus Begomovirus), also could infect $H$. rosa-sinensis (Akhtar et al. 2014; Rajeshwari et al. 2005). Begomoviruses, usually transmitted by whiteflies, can infect several dicotyledonous plants. The begomoviral genome contains circular single-strand DNA, which can be either bipartite (composed of both DNA-A and DNA-B components) or monopartite (containing a single DNA-A like component) (Hanley-Bowdoin et al. 1999). The open reading frames (ORFs) of the DNA-A component encode six genes. The virion-sense strand encodes a coat protein (ORF AV1/V1) and a movement protein (ORF AV2/V2). The virion-complementary strand encodes a replication-associated protein $(\mathrm{ORF} \mathrm{AC} 1 / \mathrm{C} 1)$, a transcriptional activator (ORF AC2/C2), a replication enhancer (ORF AC3/C3), and an AC4/C4 protein (ORF AC4/C4). (Hanley-Bowdoin et al. 1999; Zerbini et al. 2017). The virion-sense strand of DNA-B encodes a nuclear shuttle protein (ORF BV1) and the complementary strand encodes a movement protein (ORF BC1), implicated in viral movement (Zerbini et al. 2017). Some monopartite begomoviruses are associated with both DNA alphasatellite (family Alphasatellitidae) and DNA betasatellite (DNA- $\beta$ ) (genus Betasatellite; family Tolecusatellitidae) molecules. The alphasatellite is an autonomously replicating satellite that encodes a replication associated protein (Rep); however, its role in the virus infection cycle remains unknown. DNA- $\beta$ depends on the helper begomovirus for its replication (Briddon et al. 2003; Zerbini et al. 2017). DNA- $\beta$ encodes a $\beta C 1$ protein $(\mathrm{ORF} \beta C 1)$ in the complementary strand that functions as a gene-silencing suppressor (Cui et al. 2005). The $\beta C 1$ protein can enhance the virulence of the helper begomovirus and the severity of symptoms (Briddon et al. 2001, 2003; Yang et al. 2008). The criteria used to define a new species in the genus Begomovirus are based on the nucleotide sequence identity of less than $91 \%$ for the full-length 
genome of monopartite or full-length DNA-A of bipartite begomoviruses (Brown et al. 2015). The species demarcation criteria for betasatellites are based on the full-length nucleotide sequence identity set at less than $78 \%$ (Briddon et al. 2008).

In 2013, two H. rosa-sinensis plants showing leaf curling, yellow vein, and vein enation on the undersides of the leaf were collected from Changhua County in central Taiwan. Whiteflies (Bemisia tabaci cryptic species complex) (De Barro et al. 2011; Xu et al. 2010) were observed to feed on symptomatic plants. We suspected that the disease may be caused by a begomovirus based on symptomatology and the presence of whiteflies in the field. In this report, we characterized a new monopartite begomovirus, tentatively named as hibiscus yellow vein leaf curl virus (HYVLCV), from the symptomatic $H$. rosa-sinensis plants. We present biological and molecular data to support the etiology of this new disease of H. rosa-sinensis.

\section{Materials and Methods}

Source and identification of the virus. Two $H$. rosa-sinensis L., plants showing leaf curling, yellow vein, and vein enation symptoms on the undersides of the leaf, which resembled those induced by begomoviruses, were collected from Tianwei Township, Changhua County $\left(23^{\circ} 54^{\prime} 17.9^{\prime \prime} \mathrm{N} 120^{\circ} 31^{\prime} 56.5^{\prime \prime} \mathrm{E}\right)$ in central Taiwan in 2013. Total DNA was extracted from symptomatic hibiscus leaves as previously described (Chang et al. 2010) and used for PCR amplification with degenerate primers targeting the begomoviral DNA-A-like or DNA-B genome. Begomoviral DNA-A-like fragments were amplified by PCR using two degenerate primers, PAL1v1978 and PAR1c715 (Rojas et al. 1993). Two degenerate primers, DNABLC1 and DNABLV2 (Green et al. 2001), were used to amplify DNA-B. Two universal primers, $\beta 01$ and $\beta 02$ (Briddon et al. 2001), were used to amplify the begomovirus-associated DNA- $\beta$. Two pairs of universal primers, DNA101/DNA102 and UN101/UN102 (Bull et al. 2003; Xie et al. 2010), were used to amplify an alphasatellite molecule. Viral DNA fragments were amplified using Taq DNA polymerase (Protech Technology Enterprise, Taipei, Taiwan) in a thermal cycler (PTC-200; MJ Research). All oligonucleotide primers associated with begomovirus and DNA- $\beta$ used in this study are listed in Table 1.

RNA was purified from symptomatic $H$. rosa-sinensis plants using the method described by Napoli et al. (1990) and used for cDNA synthesis according to the method described by Jan et al. (2000). The resultant cDNA was used to examine the presence of HCRSV (Li and Chang 2002) and HLSV (Y. K. Chen et al. 2006) commonly infecting $H$. rosa-sinensis in Taiwan by real-time (RT)-PCR using degenerate or specific primers. Other RNA viruses, including carmoviruses, nepoviruses, potyviruses, tospoviruses, tobamoviruses, and cucumber mosaic virus (CMV), commonly occurring in Taiwan were also examined by RT-PCR using genus- specific primers (C. C. Chen et al. 2006; Colinet and Kummert 1993; Chu et al. 2001; Letschert et al. 2002; Zheng et al. 2010).

Cloning and sequencing of viral DNAs. The partial viral DNA fragment was amplified by PCR with begomovirus degenerate primers PAR1c715 and PAL1v1978, cloned into the TOPO-pCRII vector using a TA cloning kit (Invitrogen, Carlsbad, CA, U.S.A.), and sequenced. The rolling circle amplification (RCA) method (InoueNagata et al. 2004; Wu et al. 2008) was performed to amplify fulllength viral DNA concatemers with the primer HYVLCV-Rep-F using a RepliPHI Phi29 DNA Polymerase (Epicentre, Madison, WI, U.S.A.). The amplified viral DNA concatemers containing a single $N c o$ I recognition site were digested with $\mathrm{NcoI}$ (New England Biolabs, Beverly, MA, U.S.A.) to release a $2.7-\mathrm{kb}$ viral genome fragment, which was then cloned into the pCAMBIA0380 plasmid (CAMBIA, Canberra, ACT, Australia) to yield a recombinant plasmid-HibA-1 (containing the complete viral DNA-A like sequence). HibA-1 was sequenced using four primers: HYVLCV-F, HYVLCV-R, 0380-L, and 0380-R (Table 1). A 1.3-kb DNA- $\beta$ was amplified by PCR from total DNA using the universal primers $\beta 01$ and $\beta 02$ and also cloned to the TOPO-pCRII vector to produce Hibbeta-22 for sequence analysis. Sequencing was performed using an ABI PRISM 3730 automated DNA sequencer (Applied Biosystems, Hammonton, NJ, U.S.A.) available at the Biotechnology Centre, National Chung-Hsing University (Taichung, Taiwan).

Sequence and phylogenetic analysis. Database searches and comparisons of viral nucleotide sequences were performed using BLASTn and the Lasergene software package (DNASTAR, Madison, WI, U.S.A.). Sequence alignments were conducted using the ClustalW tool (Thompson et al. 1994). All pairwise comparisons of the monopartite begomoviruses and betasatellites were performed using the MUSCLE algorithm option implemented in the Species Demarcation Tool version 1.2 (SDT) (Muhire et al. 2014) and MegAlign program available in Lasergene software. Distance matrices of viral sequences and phylogenetic relationships were analyzed using the neighbor-joining method available in Molecular Evolutionary Genetics Analysis (MEGA) software MEGAX (Kumar et al. 2018) and evaluated with 1,000 bootstrap replicates. Sequences of the closely related begomoviruses and associated DNA- $\beta$ satellites were retrieved from GenBank and used for comparison and phylogenetic analysis in this study. Monopartite genome sequences of wheat dwarf virus and tomato leaf curl Taiwan virus (ToLCTWV) were used as outgroups. Recombination was predicted using the Recombination Detection Program, version 4 (RDP4) (Martin et al. 2015).

Detection and sequencing of HYVLCV from field samples. Eleven $H$. rosa-sinensis plants displaying virus-like symptoms and two nonsymptomatic plants were collected from Changhua County in 2014. Total DNA was extracted and used for PCR amplification. Two primers (HYVLCV-F and HYVLCV-R) were designed to specifically amplify the HYVLCV partial DNA region composed of the $3^{\prime} C 1$ gene, $C 2$ gene, $C 3$ gene, and $V 1$ gene. The full-length

Table 1. Primers used in this study ${ }^{\mathrm{a}}$

\begin{tabular}{|c|c|c|c|}
\hline Primer name & Primer sequence $\left(5^{\prime}-3^{\prime}\right)$ & Target, size & Reference \\
\hline PAL1v1978 & GCATCTGCAGGCCCACATYGTCTTYCCNGT & DNA-A like, approximately $1,500 \mathrm{bp}$ & Rojas et al. 1993 \\
\hline PAR1c715 & GATTTCTGCAGTTDATRTTYTCRTCCATCCA & $\ldots$ & $\ldots$ \\
\hline DNABLC1 & GTVAATGGRGTDCACTTCTG & DNA-B, approximately $2,500 \mathrm{bp}$ & Green et al. 2001 \\
\hline DNABLV2 & GAGTAGTAGTGBAKGTTGCA & $\ldots$ & $\ldots$ \\
\hline$\beta 01$ & GGTACCACTACGCTACGCAGCAGCC & DNA- $\beta$, approximately $1,300 \mathrm{bp}$ & Briddon et al. 2001 \\
\hline$\beta 02$ & GGTACCTACCCTCCCAGGGGTACAC & $\ldots$ & $\ldots$ \\
\hline 0380-L & GCGGACGTTTTTAATGTACTGAAT & Vector pCAMBIA-0380 (sequencing) & This study \\
\hline 0380-R & CTGTAATTCACACGTGGTGGTGGT & $\ldots$ & \\
\hline Actin-F & GGGATGTGAAGGAGAAGTTGGC & Actin, 79 bp & This study \\
\hline Actin-R & ACGGATGAGCTGGTCTTTGC & $\ldots$ & $\ldots$ \\
\hline HYVLCV-F (nucleotide 594) & GGTAAGCGTTTCTGTGTTAAGT & HYVLCV, 1,498 bp & This study \\
\hline HYVLCV-R (nucleotide 2,091) & GCAAATCTAGACAGGATCTTTC & $\ldots$ & $\ldots$ \\
\hline HYVLCV-Rep-F (nucleotide 1,667) & TTGGGACCAGGATTGCAAAG & HYVLCV Rep, 133 bp & This study \\
\hline HYVLCV-Rep-R (nucleotide 1,799) & ACCCGCATTTCCTCAAACAC & $\ldots$ & $\ldots$ \\
\hline
\end{tabular}

${ }^{a} \mathrm{HYVLCV}=$ hibiscus yellow vein leaf curl virus. $\mathrm{B}=\mathrm{A}$ or $\mathrm{G}, \mathrm{D}=\mathrm{A}$ or $\mathrm{C}$ or $\mathrm{G}, \mathrm{K}=\mathrm{G}$ or $\mathrm{T}, \mathrm{N}=\mathrm{A}$ or $\mathrm{T}$ or $\mathrm{G}$ or $\mathrm{C}, \mathrm{R}=\mathrm{A}$ or $\mathrm{G}, \mathrm{V}=\mathrm{A}$ or $\mathrm{C}$ or $\mathrm{G}$, and $\mathrm{Y}=\mathrm{C}$ or $\mathrm{T}$ 
HYVLCV genome was amplified from symptomatic leaves by RCA with the primer HYVLCV-Rep-F and digested with NcoI. The resultant 2.7-kb DNA fragment was cloned into pCAMBIA0380 vector to yield four clones and sequenced. The begomovirus-associated DNA$\beta$ was detected by PCR with two primers ( $\beta 01$ and $\beta 02)$ (Table 1$)$, cloned into the TOPO-pCRII vector using a TA cloning kit, and sequenced.

Pathogenicity tests via graft transmission. Viral transmission and pathogenicity were assessed by the cleft grafting method (Dijkstra and de Jager 1998). Symptomatic H. rosa-sinensis shoots were carefully cut, split into halves ( 2 to $3 \mathrm{~cm}$ deep), and used as stocks. Three $H$. rosa-sinensis shoots (presumably virus-free based on RT-PCR and PCR assays) were cut to form wedge-shaped clefts and inserted into the stocks. The grafted areas were sealed with parafilm. The plants were grown in an insect-proof greenhouse and observed for symptom development weekly. After 2 months, DNA was extracted from symptomatic and asymptomatic scions and examined by PCR using the primer pair HYVLCV-F/HYVLCV$\mathrm{R}$ to amplify the monopartite genome and $\beta 01$ and $\beta 02$ to amplify DNA- $\beta$.

Construction of infectious clones. Full-length viral DNA concatemer obtained by RCA was partially digested with $N c o$ I to produce a 5.5-kb tandem dimer, which was cloned into binary vector pCAMBIA1304 to generate the infectious clone pHib-2A, as described by Chang et al. (2010). An infectious clone of the DNA- $\beta$ was constructed according to the method described by Bang et al. (2014). A partial DNA- $\beta$ fragment (770 bp) containing the intergenic region (IR) was released from Hibbeta-22 after EcoRI and KpnI digestion and cloned into the binary vector pCAMBIA1304 to generate pHib-0.6 $\beta$. After KpnI digestion, the full-length DNA- $\beta$ was head-to-tail cloned into KpnI-digested pHib- $0.6 \beta$ to generate the infectious clone pHib-1.6 $\beta$. The construct pHib-1.6 $\beta$ was checked by EcoRI digestion. The pHib-2A and pHib-1.6 $\beta$ constructs were independently transferred into Rhizobium radiobacter (EHA 105 strain) using a Gene Pulser II electroporation system (Bio-Rad, Hercules, CA, U.S.A.).

Determination of host range. Agroinfection was performed as previously described (Chang et al. 2010). An $R$. radiobacter strain containing either a pHib-2A or a pHib-1.6 $\beta$ construct was cultured separately in Luria-Bertani broth containing $10 \mathrm{mM}$ morpholineethanesulfonic acid (pH5.6), $40 \mu \mathrm{M}$ acetosyringone (AS), and kanamycin at $50 \mathrm{ppm}$ for $16 \mathrm{~h}$. Bacterial cells were harvested by centrifugation at 5,000 rpm (JA 25.5 Rotor; Beckman Coulter) for $10 \mathrm{~min}$, resuspended in an agroinfiltration buffer $\left(10 \mathrm{mM} \mathrm{MgCl}_{2}\right.$ and $150 \mu \mathrm{M}$ AS) and adjusted to an optical density with absorbance at $550 \mathrm{~nm}$ value equivalent to 1.0. Agrobacteria suspensions were infiltrated into indicator plants. Plants used for agroinoculation included the solanaceous plants Nicotiana benthamiana (as a positive control), $N$. tabacum 'White Burley', $N$. tabacum 'Xanthi', $N$. edwardsonii, N. rustica, N. glutinosa, N. occidentalis, Capsicum annuum (sweet pepper), and Solanum lycopersicum; the cucurbitaceous plants Cucumis sativus and Citrullus lanatus; the leguminosae plants Vigna unguiculate and Pisum sativum; and the Malvaceae family plants Abelmoschus esculentus and H. rosa-sinensis. Each plant species had four biological replicates. Leaves and stems of $H$. rosa-sinensis were infiltrated with agrobacterium once a week for 3 weeks. Agrobacteria carrying pHib-2A or pHib-1.6 $\beta$ alone or in a combination were infiltrated. Plants infiltrated with $R$. radiobacter containing pCAMBIA1304 empty vector only were used as mock controls. The agroinoculated plants were maintained in an insect-proof greenhouse for at least 1 month for symptom development. Hibiscus plants treated with agroinfiltration were maintained for at least 2 months. Systemic and asymptomatic leaves were collected and total DNA was extracted from indicator plants after 1 month. PCR using primer pairs HYVLCV-F/HYVLCV-R and $\beta 01 / \beta 02$ was performed to detect HYVLCV and DNA- $\beta$, respectively.

Relative quantification of viral DNA in $N$. benthamiana. Total DNA (50 ng) was extracted from $N$. benthamiana 12 days postinoculation (dpi) and used in real-time PCR amplification with the iQ
SYBR Green Supermix (Bio-Rad, Hercules, CA, U.S.A.). Two primers (HYVLCV-Rep-F and HYVLCV-Rep-R) specifically targeting the HibA-1 C1 gene sequence were used to quantify HYVLCV. The $N$. benthamiana actin gene (accession number AY179605) was amplified with primers actin-F and actin-R as internal controls. Amplification was conducted using a CFX Connect real-time PCR detection system (Bio-Rad). HYVLCV viral DNA was normalized with respect to the actin gene using CFX Manager Software 3.1 (Bio-Rad). Standard errors were calculated from three independent experiments.

\section{Results}

Detection of a begomovirus from symptomatic $H$. rosasinensis plants. Hibiscus plants showing yellow vein, leaf curling, and vein enation (Fig. 1A to C), suspected to be caused by a virus, were collected in 2013. PCR was conducted to detect begomoviral DNA-A, DNA-B, alphasatellite, and DNA- $\beta$ with degenerate or universal primers. An expected, a 1.5-kb DNA fragment of partial viral DNA was amplified from total DNA extracted from symptomatic hibiscus leaves using the degenerate primers targeting DNA-Alike molecules (Fig. 2A) and cloned. Sequence analysis revealed that the obtained 1,460 nucleotides (nt) shared 90.6 to $90.8 \%$ identity with the monopartite genome of six CLCuMuV isolates (GenBank accession numbers KF413618, KP762786, JX914662, JX286664, JQ317603, and KF766951). Two universal primers targeting begomovirus-associated DNA- $\beta$ amplified an expected 1.3-kb DNA fragment (Fig. 2A). No product was amplified from symptomatic $H$. rosa-sinensis leaves with the alphasatellite universal primers (data not shown) and begomoviral DNA-B degenerate primers (Fig. 2A). DNA fragments with expected sizes were amplified with the primers targeting DNA-B of tomato yellow leaf curl Thailand virus and DNA- $\beta$ of ToLCTWV associated DNA- $\beta$ (positive controls) (Fig. 2A).

No product was amplified by RT-PCR with the primers targeting carmoviruses, nepoviruses, potyviruses, tospoviruses, tobamoviruses, CMV, HLSV, and HLFPV (data not shown), thus ruling out the presence of these target RNA viruses in symptomatic hibiscus plants.

Sequence determination, organization, and phylogenetic analysis of HYVLCV genome. The full-length DNA A-like molecule was amplified, sequenced, and compared to determine the taxonomic status of the monopartite begomovirus present in symptomatic $H$. rosa-sinensis plants. A 2.7-kb DNA fragment was obtained from the NcoI-digested RCA product and cloned to generate the HibA-1 clone (HYVLCV genome). Sequence analysis revealed that HYVLCV contains 2,740 nt (GenBank accession number MF140451), which was within the size range for known begomoviral monopartite genome sequences. HYVLCV was found to contain six putative ORFs, including the $V 1$ (771 nt) and $V 2$ (348 nt) genes on the viral-sense strand and the $C I$ (1092 nt), $C 2$ (453 nt), $C 3$ (405 nt), and $C 4$ (303 nt) genes on the complementary strand (Fig. 2B). A geminiviral conserved sequence ( $5^{\prime}$ TAATATTAC-3') (Stenger et al. 1991) was also found in the 269-nt IR region. A comparison of the HYVLCV sequence with those of other begomoviruses available in GenBank using BLASTn and SDT revealed that HYVLCV was closely related to 47 begomoviruses (Table 2). The full-length HYVLCV sequence shared 85.9 to $88.8 \%$ maximum nucleotide identity with 13 isolates of CLCuMuV (GenBank accession number KY373212), a monopartite begomovirus known to infect hibiscus in India (Rajeshwari et al. 2005). According to the current criteria of the International Committee on Taxonomy of Viruses (ICTV), a new begomviral species is determined by the fulllength genome of a monopartite genome or the full-length of DNA-A sequence identity set on less than $91 \%$. Thus, we proposed HYVLCV as a tentative new species in the genus Begomovirus. Phylogenetic analyses of HYVLCV and 47 closely related begomoviruses available in the GenBank database revealed two distinct clusters. One cluster consisted of malvastrum yellow vein virus (MaYVV), tomato leaf curl New Delhi virus 2 (ToLCNDV2), pea leaf distortion virus, cotton leaf curl Bangalore virus, kenaf leaf curl virus (KLCuV), hollyhock leaf curl virus, eclipta yellow vein virus, and malvastrum yellow 
mosaic virus isolates. Another cluster consisted of CLCuMuV and CLCuKoV-Bu isolates (Fig. 3A). Isolates of HYVLCV formed a distinct clade from other begomoviruses and was close to the CLCuMuV clade (Fig. 3A).

Analysis of DNA- $\beta$ associated with HYVLCV. The full-length DNA- $\beta$ component was amplified by PCR (Fig. $2 \mathrm{~A}$ ) and cloned to generate the Hibbeta-22 clone. Sequence analysis revealed that Hibbeta-22 contains 1,355 nt (GenBank accession number MF140456), which encodes a putative $\beta C 1$ (357 amino acid) in the complementary sense (Fig. 2B). Comparisons of the Hibbeta-22 sequence with those of other DNA- $\beta$ available in GenBank using BLASTn and SDT revealed that Hibbeta-22 was closely related to 31 DNA- $\beta$ of begomoviruses infecting the family Malvaceae (Table 3). Phylogenetic analysis showed that Hibbeta-22 was most close to the malvastrum yellow vein betasatellite (MaYVB) clade compared with other DNA- $\beta$ sequences (Fig. 3B). Hibbeta-22 shared 78.4 to $78.6 \%$ nucleotide identity with five MaYVB isolates, which was slightly higher than the ICTV threshold $(78 \%)$ set for DNA- $\beta$ (Briddon et al. 2008). Therefore, this DNA- $\beta$ associated with HYVLCV was considered a divergent isolate of MaYVB and tentatively named MaYVB-Hib.

Virus detection of field samples. PCR analysis of 11 symptomatic hibiscus samples collected from Changhua County in 2014 revealed that two primers (HYVLCV-F and HYVLCV-R) (Table 1) were able to amplify an expected 1.5-kb DNA fragment from 10 of the 11 test samples and a positive control sample. An expected $1.3 \mathrm{~kb}$ of DNA- $\beta$ was amplified from 8 of 11 test samples and the positive control sample. No DNA was amplified from nonsymptomatic plants using these primers (data not shown). Full-length DNA A-like fragments were amplified from four samples and cloned into pCAMBIA0380 vector to yield Hib2-2 (accession number MF140452), Hib5-5 (MF140453), Hib6-2 (MF140454), and Hib8-8 (MF140455) and sequenced. Sequence analysis revealed that the four viral clones (Hib2-2, Hib5-5, Hib6-2, and Hib8-8) (2,740 nt) shared 99.9 to
$100 \%$ nucleotide identity with HibA- 1 . The full-length DNA- $\beta$ was amplified from two samples and cloned to generate Hibbeta-2 and Hibbeta-8. Sequence analysis revealed that Hibbeta-2 and Hibbeta-8 shared 99.3 to $99.6 \%$ nucleotide identity with MaYVB-Hib. Hibbeta-2 and Hibbeta- 8 shared nucleotide identity ranging from 78.4 to $79 \%$ with five MaYVB isolates.

Analysis for recombination. Recombination was examined using the RDP4 analysis. Alignment of HYVLCV with monopartite begomoviral sequences retrieved from the GenBank sequence database (Fig. 3A) revealed that recombination likely occurred in all HYVLCV isolates. The RDP recombination analysis identified a putative recombination event in the HYVLCV with different $P$ values depending on the methods used (Table 4). The putative recombination breakpoints were predicted to be located within the AC1 and IR region (1,729 to 2,728). The RDP analysis indicated that KLCuV-Y341 (isolate TH4872-9, accession number KY373212) was likely the major parent of HYVLCV and the minor parent was CLCuMuV-TH4872-9 (isolate Y341, accession number FN806778). HYVLCV nucleotides $(1,729$ to 2,728$)$ showed $100 \%$ identity with the minor parent. The remaining nucleotides (1 to 1,728 and 2,729 to 2,740 ) showed $92.3 \%$ identity with the major parent. Similar analysis of MaYVB-Hib and $\beta$ satellite sequences from the database (Fig. 3B) revealed no recombination within MaYVB-Hib.

Back inoculation via graft transmission. Assays for virus transmission were performed by cleft grafting. The three virus-free $H$. rosa-sinensis (Fig. 1D) scions grafted onto HYVLCV-positive stocks developed yellow vein symptom at 30 to 40 dpi (Fig. 1E) followed by vein enation and leaf curl symptoms at $60 \mathrm{dpi}$. The presence of HYVLCV and MaYVB-Hib in the symptomatic $H$. rosa-sinensis scions was confirmed by PCR (Fig. 1F).

Infectivity assays of HYVLCV and its associated $\beta$ satellite MaYVB-Hib. Agroinfiltration of pHib-2A or pHib-1.6 $\beta$ (Fig. 4A) alone into $N$. benthamiana plants resulted in no visible symptom at
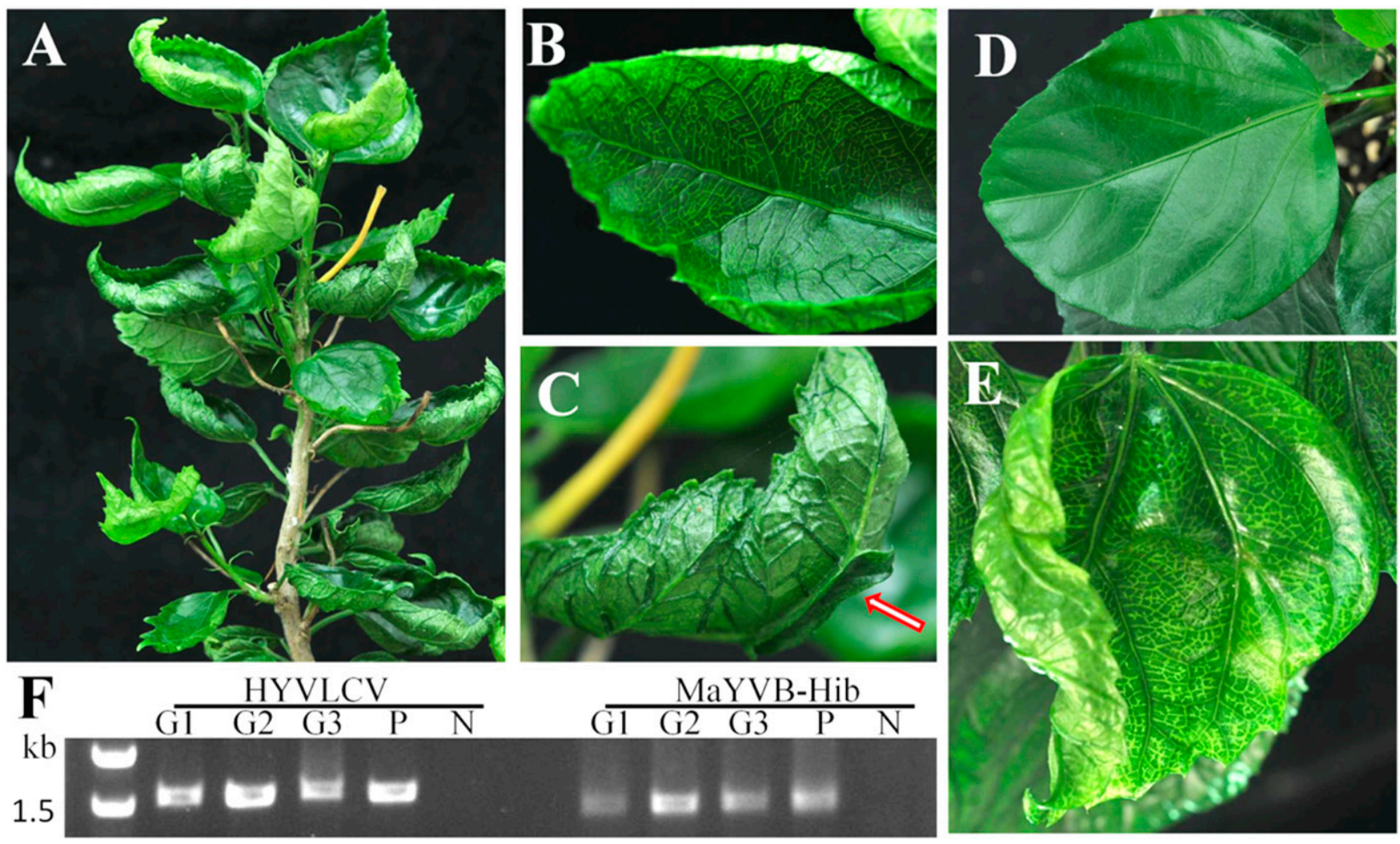

Fig. 1. Symptoms of diseased Hibiscus rosa-sinensis plants. H. rosa-sinensis showing the symptoms of $\mathbf{A}$, leaf curling; $\mathbf{B}$, vein yellowing, and $\mathbf{C}$, enation (indicated by arrows) on the abaxial surface of the leaf. D, Healthy leaf. E, Leaf vein yellowing was observed on $H$. rosa-sinensis scions 1 month after being grafted onto a diseased $H$. rosa-sinensis plant. $\mathbf{F}$, Presence of hibiscus yellow vein leaf curl virus (HYVLCV) and malvastrum yellow vein betasatellite (MaYVB)-Hib in three grafting hibiscus was confirmed by PCR using primers specially targeting HYVLCV or MaYVB-Hib. Abbreviations: $\mathrm{G}=$ grafting hibiscus, $\mathrm{P}=\mathrm{HYVLCV-infected} \mathrm{hibiscus} \mathrm{collected} \mathrm{from} \mathrm{field,} \mathrm{and} \mathrm{N}=$ healthy hibiscus. 
12 dpi (Fig. 4B and C). However, plants coinfected with pHib-2A and pHib-1.6 $\beta$ developed severe mosaic, vein yellowing, and leaf curl symptoms at 12 dpi (Fig. 4D). Plants infiltrated with pHib$2 \mathrm{~A}$ alone developed yellowing and leaf curling at $28 \mathrm{dpi}$ (Fig. 4E). The presence of HYVLCV, MaYVB-Hib, or both in N. benthamiana systemic leaves was confirmed by PCR. HYVLCV was detected in plants infiltrated with $\mathrm{pHib}-2 \mathrm{~A}$ alone and coinoculated with pHib-1.6 $\beta$. MaYVB-Hib was detected only in plants coinoculated with pHib-2A and pHib-1.6 $\beta$. Neither HYVLCV nor MaYVB-Hib was detected in plants treated with empty vector (Fig. 4F). Similar results were observed from analysis of realtime PCR. Plants coinoculated with pHib-2A and pHib-1.6 $\beta$ had HYVLCV DNA levels twofold higher than those inoculated with pHib-2A alone (Fig. 5).
Determination of host range by agroinoculation. In total, 15 different plant species ( $n=4$ plants/species) were tested for susceptibility to HYVLCV by agroinoculation. $N$. benthamiana, $N$. edwardsonii, N. tabacum 'Xanthi', and N. tabacum 'White Burley' developed systemic symptoms after agroinoculation (Table 5). All plant species showed mosaic, vein yellowing, and leaf curl symptoms on the apical leaves. The presence of HYVLCV and MaYVB-Hib in symptomatic plants was confirmed by PCR assays. No visible symptom was observed on the Solanaceae plants $N$. glutinosa, $N$. occidentalis, $N$. rustica, Capsicum annuum (sweet pepper), and S. lycopersicum; the cucurbitaceous plants Cucumis sativus and Citrullus lanatus; the Leguminosae plants $V$. unguiculate and $P$. sativum; and the Malvaceae plants A. esculentus and $H$. rosasinensis at $30 \mathrm{dpi}$. No symptom was observed on $H$. rosa-sinensis

\section{A Monopartite}
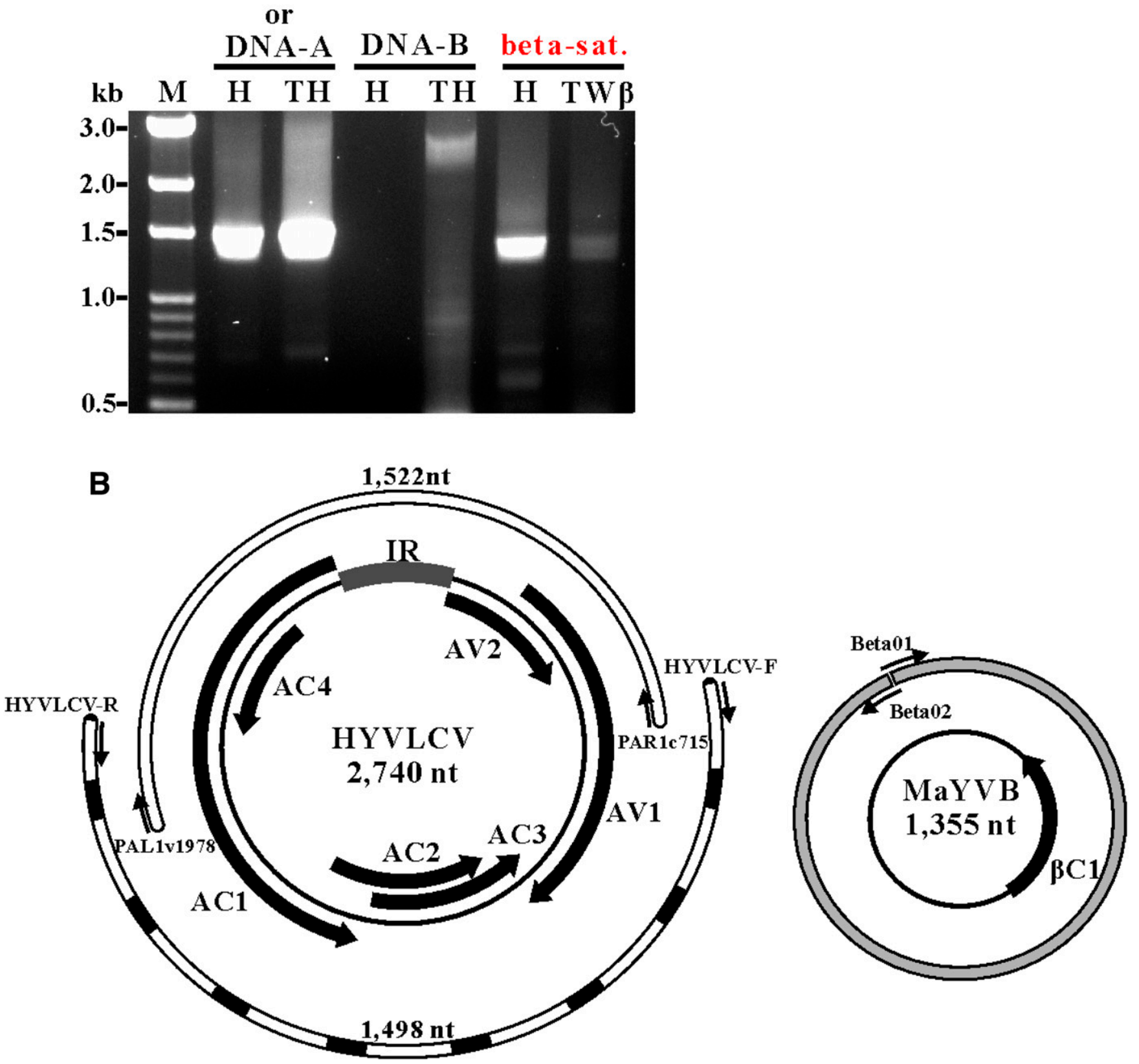

Fig. 2. Detection of hibiscus yellow vein leaf curl virus (HYVLCV) isolate HibA-1 by PCR. A, Amplification of begomoviral monopartite, DNA-A, DNA-B, and associated $\beta$ satellite (beta-sat) by PCR using degenerate and universal primers. Lane $M=$ marker, lane H = HYVLCV isolate HibA-1, lane TH = tomato yellow leaf curl Thailand virus, and lane TW $\beta=$ tomato leaf curl Taiwan virus associated $\beta$ satellite. B, Schematics showing genome organization of the HYVLCV genome and its associated $\beta$ satellite malvastrum yellow vein betasatellite (MaYVB)-Hib; $\mathrm{nt}=$ nucleotides. Relative positions of the primers used in this study and the size of the amplified fragments are also indicated. 
leaves at 60 dpi. PCR analysis of these plants also resulted in negative reactions.

\section{Discussion}

In this study, we characterized a new begomovirus named HYVLCV from diseased $H$. rosa-sinensis plants showing leaf curling, yellow vein, and vein enation symptoms. The causal agent contains a monopartite begomovirus and a helper DNA- $\beta$ satellite. Sequence analysis reveals that HYVLCV shares 85.9 to $88.8 \%$ nucleotide identity with $13 \mathrm{CLCuMuV}$ isolates and 86.0 to $88.7 \%$ nucleotide identity with seven MaYVV isolates, which are also monopartite begomoviruses. $\mathrm{CLCuMuV}$ has been reported to infect hibiscus in India (Rajeshwari et al. 2005). MaYVV has been reported to infect Sida acuta (isolate C [CN-Yn340-Sid-08]) (Li and Zhou 2010) and Malvastrum coromandelianum (isolates A[CN-Yn278-04] and $\mathrm{A}[\mathrm{Y} 281]$ ) in China. Based on the demarcation of begomovirus species set at $<91 \%$ nucleotide identity for monopartite genome (Brown et al. 2015), our results indicate that HYVLCV is a putative

Table 2. Pairwise comparisons of full-length genome nucleotide and nucleotide/deduced amino acid sequences of open reading frames (ORFs) of hibiscus yellow vein leaf curl virus (GenBank accession number MF140451) with closely related monopartite begomoviruses available in GenBank

\begin{tabular}{|c|c|c|c|c|c|c|c|}
\hline \multirow[b]{2}{*}{ Virus $^{a}$} & \multirow[b]{2}{*}{ Nucleotides $(\%)^{\mathbf{b}}$} & \multicolumn{6}{|c|}{ Nucleotides/amino acids } \\
\hline & & $V 1(\%)$ & $V 2(\%)$ & $C I(\%)$ & $C 2(\%)$ & C3 (\%) & C4 (\%) \\
\hline CLCuMuV (13) & $85.9-88.8$ & 79.8-81.6/90.3-91.1 & $79.6-80.2 / 63.8-74.1$ & $90.6-97.6 / 89.8-98.4$ & $88.2-91.8 / 66.9-86.8$ & $84.1-87.9 / 69.6-87.3$ & $93.4-100 / 85.1-100$ \\
\hline MaYVV (7) & $5.0-88.7$ & $91.2-92.7 / 95.7-97.7$ & 93.4-95.1/90.3-95.7 & $81.2-86.4 / 83.5-89.3$ & 93.4-94.5/88.7-90.7 & 91.9-94.6/88.1-92.6 & $74.9-85.9 / 48.0-71.1$ \\
\hline ToLCNDV2 (1) & 88.3 & $88.8 / 95.3$ & $91.7 / 86.2$ & $90.2 / 91.2$ & $91.6 / 86.1$ & $90.3 / 83.2$ & $92.4 / 85.1$ \\
\hline PeLDV(4) & $88.3-88.4$ & $91.2-91.8 / 94.2-94.9$ & $89.4-90.8 / 89.7-92.2$ & 87.7-88.0/91.2-91.7 & $92.5 / 88.7$ & $92.1 / 89.6$ & $88.4 / 74.3$ \\
\hline CLCuBaV (2) & -87.6 & 87.9-88.2/93.4-93.8 & $89.4-89.7 / 87.1-87.9$ & $85.7-90.4 / 87.6-91.7$ & $90.3-90.9 / 84.1-87.4$ & $88.1-89.4 / 83.7-85.2$ & $88.4-94.1 / 75.2-90.1$ \\
\hline $\mathrm{KLCuV}(3)$ & $86.7-87.2$ & $90.7-91.7 / 95.7-96.1$ & $92.0-95.4 / 89.7-94.0$ & $83.6-83.9 / 86.0-86.3$ & $94.0-94.3 / 88.1-90.1$ & $92.6-95.1 / 89.6-93.3$ & $75.3-77.0 / 48.0-50.0$ \\
\hline HoLCV (3) & $84.9-87.1$ & 87.4-87.8/94.9-95.3 & $89.1-90.8 / 88.8-89.7$ & 83.9-87.9/87.9-90.7 & $89.4-90.3 / 81.5-82.8$ & $88.4-90.8 / 85.2-85.9$ & $86.8-91.1 / 71.3-78.2$ \\
\hline EcYVV (3) & $85.8-86.5$ & $86.9-88.7 / 93.4-95.3$ & 86.9-88.7/87.9-91.4 & $84.5-84.6 / 87.3-87.8$ & $89.2-91.2 / 82.1-85.4$ & $89.6-89.9 / 85.9-88.1$ & $88.1-88.4 / 76.2-77.2$ \\
\hline CLCuKoV-Bu (9) & $85.4-86.3$ & 79.4-80.8/91.4-92.6 & $75.6-76.4 / 66.4-67.2$ & $94.6-95.3 / 94.5-96.2$ & $\mathrm{NA}^{\mathrm{c}}$ & $76.8-86.9 / 71.9-81.5$ & $97.0-98.5 / 92.1-97.0$ \\
\hline MaYMV (2) & $85.3-85.4$ & $80.3-81.2 / 85.6$ & $96.3 / 96.6$ & $85.0-85.5 / 88.7-89.0$ & $93.6 / 90.7$ & $93.8 / 91.1$ & $86.9-88.4 / 70.1-72.3$ \\
\hline
\end{tabular}

a Abbreviations: malvastrum yellow vein virus (MaYVV), cotton leaf curl Multan virus (CLCuMuV), tomato leaf curl New Delhi virus 2 (ToLCNDV2), pea leaf distortion virus (PeLDV), cotton leaf curl Bangalore virus (CLCuBaV), kenaf leaf curl virus (KLCuV), hollyhock leaf curl virus (HoLCV), eclipta yellow vein virus (EcYVV), cotton leaf curl Kokhran virus-Burewala (CLCuKoV-Bu), and malvastrum yellow mosaic virus (MaYMV). Numbers within parentheses represent the number of viral sequences used for comparison. ${ }^{\mathrm{b}}$ Full-length nucleotides.

c The CLCuKoV-Bu ORF C2 is currently not available for pairwise comparison.

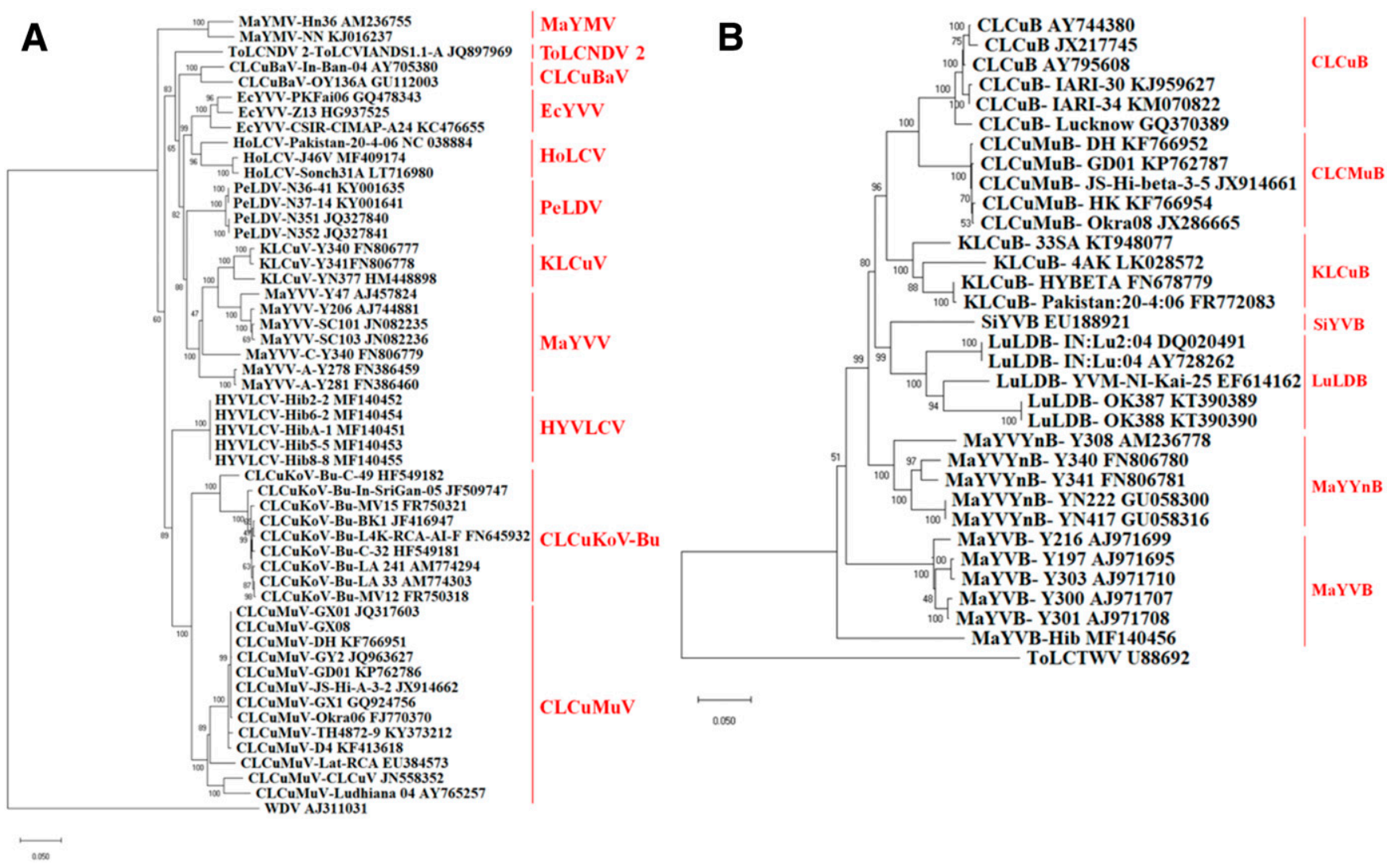

Fig. 3. Phylogenetic relationships of $\mathbf{A}$, hibiscus yellow vein leaf curl virus (HYVLCV) genome and $\mathbf{B}$, its associated $\beta$ satellite malvastrum yellow vein betasatellite (MaYVB)-Hib with those of closely related begomoviruses. The phylogenetic tree was constructed by the neighbor-joining method with 1,000 bootstrap replicates available in MEGAX. Abbreviations: malvastrum yellow vein virus (MaYVV), cotton leaf curl Multan virus (CLCuMuV), tomato leaf curl New Delhi virus 2 (ToLCNDV2), pea leaf distortion virus (PeLDV), cotton leaf curl Bangalore virus (CLCuBaV), kenaf leaf curl virus (KLCuV), hollyhock leaf curl virus (HoLCV), eclipta yellow vein virus (EcYVV), cotton leaf curl Kokhran virus-Burewala (CLCuKoV-Bu), malvastrum yellow mosaic virus (MaYMV), malvastrum yellow vein betasatellite (MaYVB), malvastrum yellow vein Yunnan betasatellite (MaYVYnB), luffa leaf distortion betasatellite (LuLDB), cotton leaf curl Multan betasatellite (CLCuMuB), kenaf leaf curl betasatellite (KLCuB), sida yellow vein betasatellite (SiYVB), and cotton leaf curl betasatellite (CLCuB). DNA sequences of wheat dwarf virus (WDV) and tomato leaf curl Taiwan virus (ToLCTWV) were used as outgroups. 
Table 3. Pairwise comparisons of full-length genome nucleotide sequence of malvastrum yellow vein betasatellite (MaYVB)-Hib (GenBank accession number MF140456) with closely related begomovirus-associated $\beta$ satellites available in GenBank

\begin{tabular}{lcc}
\hline Virus name $^{\text {a }}$ & $\boldsymbol{\beta}$ satellite DNA nucleotides $(\%)$ & $\boldsymbol{\beta C 1}$ nucleotides $(\%)$ \\
\hline MaYVB (5) & $78.4-78.6$ & $84.6-86.0$ \\
MaYVYnB (5) & $77.2-78.3$ & $81.0-83.2$ \\
LuLDB (5) & $73.2-78.4$ & $81.5-81.8$ \\
CLCuMuB (5) & $74.5-76.1$ & $80.7-81.0$ \\
KLCuB (4) & $72.7-76.5$ & $79.8-80.1$ \\
SiYVB (1) & 76.3 & 78.4 \\
CLCuB (6) & $73.4-74.3$ & $79.7-84.0$ \\
\hline
\end{tabular}

a Abbreviations: malvastrum yellow vein betasatellite (MaYVB), malvastrum yellow vein Yunnan betasatellite (MaYVYnB), luffa leaf distortion betasatellite (LuLDB), cotton leaf curl Multan betasatellite (CLCuMuB), kenaf leaf curl betasatellite (KLCuB), sida yellow vein betasatellite (SiYVB), and cotton leaf curl betasatellite $(\mathrm{CLCuB})$. Numbers within parentheses represent the number of viral sequences used for comparison.

Table 4. Detection of a putative recombination event in hibiscus yellow vein leaf curl virus (HYVLCV) ${ }^{\mathrm{a}}$

\begin{tabular}{|c|c|c|c|c|c|c|c|c|c|}
\hline \multirow[b]{2}{*}{ Event } & \multirow[b]{2}{*}{ Region } & \multirow[b]{2}{*}{ Major parent } & \multirow[b]{2}{*}{ Minor parent } & \multicolumn{6}{|c|}{ Detection method, average $P$ value } \\
\hline & & & & RDP & GENCONV & BootScan & MaxChi & Chimaera & 3Seq \\
\hline HYVLCV & $1,729-2,728$ & KLCuV-Y341 (92.3\%) & CLCuMuV-TH4872-9 (100\%) & $4.863 \times 10^{-62}$ & $7.007 \times 10^{-52}$ & $2.642 \times 10^{-46}$ & $2.485 \times 10^{-7}$ & $8.347 \times 10^{-31}$ & $9.365 \times 10^{-13}$ \\
\hline
\end{tabular}

a Abbreviations: kenaf leaf curl virus (KLCuV), cotton leaf curl Multan virus (CLCuMuV), and RDP = Recombination Detection Program.
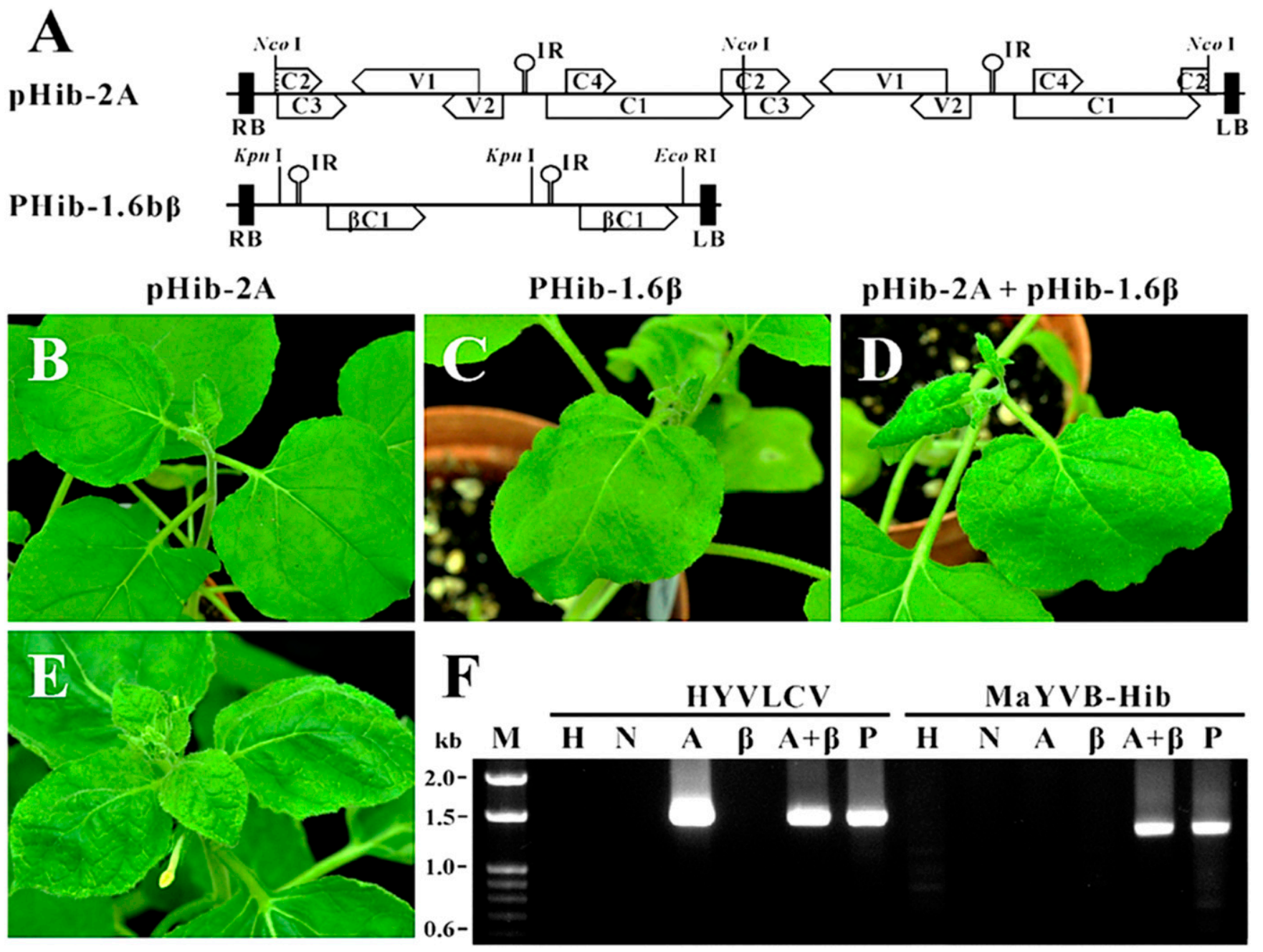

Fig. 4. Agroinoculation assays of infectious hibiscus yellow vein leaf curl virus (HYVLCV) viral DNA and associated betasatellite malvastrum yellow vein betasatellite (MaYVB)-Hib. A, Construction map of infectious clones, tandem-repeated HYVLCV genome (pHib-2A), and partial-repeated associated betasatellite DNA (pHib-1.6 3 ). Nicotiana benthamiana inoculated with B, HYVLCV or C, MaYVB-Hib alone shows no symptoms at 12 days postinoculation (dpi), whereas D, coinoculation results in mosaic, vein yellowing, and leaf curl symptoms at 12 dpi. E, N. benthamiana inoculated with HYVLCV alone shows yellowing and leaf curling symptoms at 28 dpi. F, The presence of HYVLCV and MaYVB-Hib was confirmed (12 dpi) by PCR using primers specially targeting HYVLCV or MaYVB-Hib. Abbreviations: $\mathrm{H}=$ healthy $N$. benthamiana, $\mathrm{N}=$ agroinfiltration with empty vector as a mock

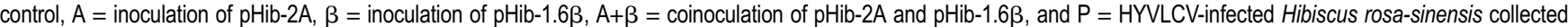
from field. 
new begomovirus. RDP4 analysis of the complete sequence of HYVLCV with other monopartite begomoviral sequences in the database reveals that HYVLCV is likely a result of viral recombination between $\mathrm{CLCuMuV}$ (minor parent) and $\mathrm{KLCuV}$ (major parent). Both CLCuMuV and $\mathrm{KLCuV}$ have been reported to infect Hibiscus plants (Paul et al. 2009; Rajeshwari et al. 2005).

Plants infected by begomoviruses carrying DNA- $\beta$ satellites often show enation symptoms (Briddon et al. 2003; Tahir and Mansoor 2011). Similar vein enation was observed on the abaxial surface of diseased H. rosa-sinensis leaves (Fig. 1C). It has also been reported that transgenic Arabidopsis plants expressing $\beta \mathrm{C} 1$ of DNA- $\beta$ satellite alone exhibit vein enation (Yang et al. 2008). A begomoviral DNA- $\beta$ satellite (Hibbeta-22) designated MaYVB-Hib was detected, cloned, and sequenced. Pairwise examination of nucleotide sequences of $\beta$ satellites shares higher than $78 \%$ nucleotide identity with those of MaYVB, malvastrum yellow vein Yunnan betasatellite (MaYVYnB), and luffa leaf distortion betasatellite (LuLDB). SDT and pairwise comparisons analyses

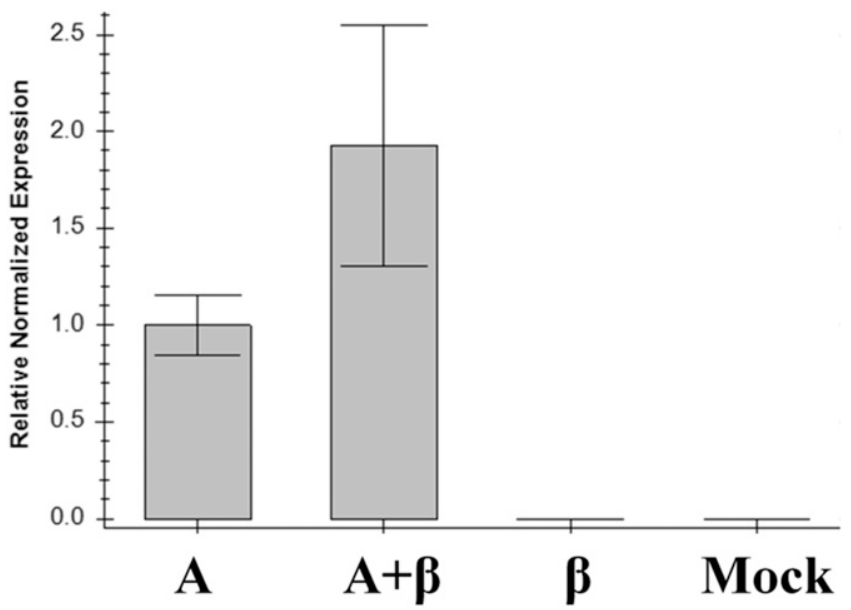

Fig. 5. Semiquantitative assessment of hibiscus yellow vein leaf curl virus (HYVLCV) in Nicotiana benthamiana (12 days postinoculation) by real-time PCR. N. benthamiana was infiltrated with empty vector (Mock), pHib-2A (A), pHib-1.6ß ( $\beta$ ), or a combination

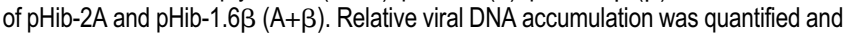
normalized with respect to the $N$. benthamiana actin gene. also reveal that MaYVB-Hib shows low nucleotide identity with MaYVYnB (78.3\%) and LuLDB (78.4\%). MaYVB-Hib shares the highest nucleotide identity with MaYVB (78.6\%). Two field plants infected with the HYVLCV without DNA- $\beta$ display milder vein yellowing and leaf curl symptoms compared with the HYVLCV with DNA- $\beta$. The $\beta C 1$ gene in the DNA- $\beta$ has been demonstrated to be required for virulence (Briddon et al. 2001; Mansoor et al. 2003; Yang et al. 2008). HYVLCV was not detected by DNA-A-specific primers in one hibiscus plant showing viruslike symptoms, which indicates that the symptoms were caused by another virus rather than HYVLCV.

Experiments have demonstrated that HYVLCV alone could infect $N$. benthamiana and induce yellowing and mild leaf curling symptoms at $28 \mathrm{dpi}$ but the timing for symptoms was considerably longer and symptom development was less severe than for the plants coinfected with HYVLCV and MaYVB-Hib, which developed severe mosaic, vein yellowing, and leaf curl symptoms at 12 dpi. Also, qPCR analysis showed that the presence of MaYVBHib enhances the titer of HYVLCV in the N. benthamiana. This result is similar to those described for interaction between tomato leaf curl China virus and tomato leaf curl China virus $\beta$ satellites (Yang et al. 2011). However, agroinfiltration assays coupled with PCR examination revealed that MaYVB-Hib alone fails to live in host plants without its helper virus. Although both HYVLCV and MaYVB-Hib, after being coinoculated, are biologically active and capable of causing symptoms on $N$. benthamiana, the agroinoculation of infectious clones of both molecules fails to infect $H$. rosa-sinensis after several attempts (data not shown). Studies in okra yellow crinkle virus and cotton leaf curl Gezira virus revealed that infectious clones of either virus, after being introduced by agroinoculation, fail to infect malvaceous okra plants, presumably due to the incompatibility with Agrobacterium tumefaciens (Kon et al. 2009). Studies in jatropha mosaic virus also revealed that infectious clones are unable to establish infectivity in jatropha by agroinoculation (Melgarejo et al. 2015). Moreover, infectious clones of CLCuMuV have been shown to exhibit less infectivity using either Agrobacterium-mediated inoculation or the biolistic system (Briddon et al. 2001). The mechanisms attributable to the failure of agroinoculation remain elusive; however, it could be simply due to limited host ranges of A. tumefaciens (Saeed 2008). This problem can be resolved by grafting or whitefly transmission of the virus. Two H. rosa-sinensis-infecting begomoviruses, CLCuMuV and $\mathrm{CLCuKoV-Bu}$, have been shown to be pathogenic in back-inoculation

Table 5. Plant species agroinfiltration with infectious hibiscus yellow vein leaf curl virus HYVLCV viral DNA and associated betasatellite

\begin{tabular}{|c|c|c|c|c|}
\hline Family, species & Infected/inoculated & Latent period (days) & Virus detection (PCR)-A/ $\boldsymbol{\beta}^{\mathbf{a}}$ & Symptoms ${ }^{\mathbf{b}}$ \\
\hline \multicolumn{5}{|l|}{ Cucurbitaceae } \\
\hline Cucumis sativus & $0 / 4$ & $\ldots$ & - & NS \\
\hline Citrullus lanatus & $0 / 4$ & $\ldots$ & - & NS \\
\hline \multicolumn{5}{|l|}{ Legumisoae } \\
\hline Vigna unguiculate & $0 / 4$ & $\ldots$ & - & NS \\
\hline Pisum sativum & $0 / 4$ & $\ldots$ & - & NS \\
\hline \multicolumn{5}{|l|}{ Malvaceae } \\
\hline Abelmoschus esculentus & $0 / 4$ & $\ldots$ & - & NS \\
\hline Hibiscus rosa-sinensis & $0 / 4$ & $\ldots$ & - & NS \\
\hline \multicolumn{5}{|l|}{ Solanaceous } \\
\hline Nicotiana benthamiana & $4 / 4$ & $7-9$ & $+/+$ & Mo, YV, LC \\
\hline N. tabacum 'White Burley' & $1 / 4$ & 18 & $+/+$ & Mo, YV, LC, VE \\
\hline N. tabacum 'Xanthi' & $1 / 4$ & 18 & $+/+$ & Mo, YV, LC, VE \\
\hline N. glutinosa & $0 / 4$ & $\ldots$ & - & NS \\
\hline N. occidentalis & $0 / 4$ & $\ldots$ & - & NS \\
\hline N. edwardsonii & $4 / 4$ & $7-9$ & $+/+$ & Mo, YV, LC \\
\hline N. rustica & $0 / 4$ & $\ldots$ & - & NS \\
\hline Capsicum аппиит & $0 / 4$ & $\ldots$ & - & NS \\
\hline Solanum lycopersicum & $0 / 4$ & $\ldots$ & - & NS \\
\hline
\end{tabular}

${ }^{a}$ Symbols: + indicates the presence of HYVLCV and associated betasatellite was confirmed (12 days postinoculation) by PCR using primers specially targeting HYVLCV or associated betasatellite and - indicates that no viral DNA was detected by PCR.

${ }^{\mathrm{b}} \mathrm{NS}=$ no symptoms, $\mathrm{Mo}=$ mosaic, $\mathrm{LC}=$ leaf curl, $\mathrm{YV}=$ yellow vein, and $\mathrm{VE}=$ vein enation 
assays using grafting or whitefly transmission (Akhtar et al. 2014; Rajeshwari et al. 2005). In the present study, we have also demonstrated that HYVLCV can be transmitted via grafting. Three HYVLCV-free H. rosa-sinensis scions developed leaf yellow vein symptoms 30 to 40 days after grafting onto the HYVLCV-infected stocks and developed vein enation and leaf curl symptoms at $60 \mathrm{dpi}$. HYVLCV and MaYVB-Hib could be detected in the symptomatic scions by PCR (Fig. 1F). The results confirm the infectivity of HYVLCV in $H$. rosa-sinensis.

$H$. rosa-sinensis is often propagated via vegetative cuttings in Taiwan. Sequence analysis of four HYVLCV clones (Hib2-2, Hib5-5, Hib6-2, and Hib8-8) revealed 100\% nucleotide identity of genomic DNA sequences with HYVLCV. Future studies should investigate the ability of whiteflies to transmit the newly identified begomovirus, which may contribute to its rapid spread. Although agroinoculation has revealed that HYVLCV can propagate in certain Nicotiana spp., the exact host range of HYVLCV remains unknown. Primers specifically targeting the HYVLCV monopartite genome have been tested for detection of the virus from fieldcollected samples, which will be useful for fast and reliable diagnosis of HYVLCV. The primers also could facilitate determination of the host range of HYVLCV in nature.

\section{Acknowledgments}

We thank K.-R. Chung, Distinguished Professor of the National Chung Hsing University, for his critical editing and review of the manuscript.

\section{Literature Cited}

Adkins, S., Kamenova, I., Achor, D., and Lewandowski, D. J. 2003. Biological and molecular characterization of a novel tobamovirus with a unique host range. Plant Dis. 87:1190-1196.

Adkins, S., Kamenova, I., Chiemsombat, P., Baker, C. A., and Lewandowski, D. J. 2006. Tobamoviruses from hibiscus in Florida and beyond. Acta Hortic. 722: 65-70.

Akhtar, K. P., Ullah, R., Saeed, M., Sarwar, N., and Mansoor, S. 2014. China rose (Hibiscus rosa-sinensis): A new natural host of Cotton leaf curl Burewala virus in Pakistan. J. Plant Pathol. 96:385-389.

Bang, B., Lee, J., Kim, S., Park, J., Nguyen, T. T., and Seo, Y. S. 2014. A rapid and efficient method for construction of an infectious clone of tomato yellow leaf curl virus. Plant Pathol. J. 30:310-315.

Briddon, R. W., Brown, J. K., Moriones, E., Stanley, J., Zerbini, M., Zhou, X., and Fauquet, C. M. 2008. Recommendations for the classification and nomenclature of the DNA- $\beta$ satellites of begomoviruses. Arch. Virol. 153:763-781.

Briddon, R. W., Bull, S. E., Amin, I., Idris, A. M., Mansoor, S., Bedford, I. D., Dhawan, P., Rishi, N., Siwatch, S. S., Abdel-Salam, A. M., Brown, J. K., Zafar, Y., and Markham, P. G. 2003. Diversity of DNA $\beta$, a satellite molecule associated with some monopartite begomoviruses. Virology 312: 106-121.

Briddon, R. W., Mansoor, S., Bedford, I. D., Pinner, M. S., Saunders, K., Stanley, J., Zafar, Y., Malik, K. A., and Markham, P. G. 2001. Identification of DNA components required for induction of cotton leaf curl disease. Virology 285: 234-243.

Brown, J. K., Zerbini, F. M., Navas-Castillo, J., Moriones, E., Ramos-Sobrinho, R., Silva, J. C. F., Fiallo-Olivé, E., Briddon, R. W., Hernández-Zepeda, C., Idris, A., Malathi, V. G., Martin, D. P., Rivera-Bustamante, R., Ueda, S., and Varsani, A. 2015. Revision of Begomovirus taxonomy based on pairwise sequence comparisons. Arch. Virol. 160:1593-1619.

Brunt, A. A., Barton, R. J., Phillips, S. U. E., and Lana, A. O. 1980. Hibiscus latent ringspot virus, a newly recognised virus from Hibiscus rosa-sinensis (Malvaceae) in western Nigeria. Ann. Appl. Biol. 96:37-43.

Bull, S. E., Briddon, R. W., and Markham, P. G. 2003. Universal primers for the PCR-mediated amplification of DNA 1: A satellite-like molecule associated with begomovirus-DNA b complexes. Mol. Biotechnol. 23:83-86.

Chang, H. H., Ku, H. M., Tsai, W. S., Chien, R. C., and Jan, F. J. 2010. Identification and characterization of a mechanical transmissible begomovirus causing leaf curl on oriental melon. Eur. J. Plant Pathol. 127:219-228.

Chen, C. C., Hsu, H. T., Cheng, Y. H., Huang, C. H., Liao, J. Y., Tsai, H. T., and Chang, C. A. 2006. Molecular and serological characterization of a distinct potyvirus causing latent infection in calla lilies. Bot. Stud. (Taipei, Taiwan) 47:369-378.

Chen, Y. K., Chen, T. C., Liu, F. L., Yeh, S. D., Chen, C. C., Bau, H. J., and Hsu, H. T. 2006. Molecular characterization of a hibiscus-infecting tobamovirus in Taiwan. Acta Hortic. 722:59-64.

Chu, F. H., Chao, C. H., Chung, M. H., Chen, C. C., and Yeh, S. D. 2001. Completion of the genome sequence of Watermelon silver mottle virus and utilization of degenerate primers for detecting tospoviruses in five serogroups. Phytopathology 91:361-368.
Colinet, D., and Kummert, J. 1993. Identification of a sweet potato feathery mottle virus isolate from China (SPFMV-CH) by the polymerase chain reaction with degenerate primers. J. Virol. Methods 45:149-159.

Cui, X., Li, G., Wang, D., Hu, D., and Zhou, X. P. 2005. A begomovirus DNA $\beta$-encoded protein binds DNA, functions as a suppressor of RNA silencing, and targets the cell nucleus. J. Virol. 79:10764-10775.

De Barro, P. J., Liu, S. S., Boykin, L. M., and Dinsdale, A. B. 2011. Bemisia tabaci: A statement of species status. Annu. Rev. Entomol. 56:1-19.

De Stradis, A., Parrella, G., Vovlas, C., and Ragozzino, A. 2008. Vein yellowing of Hibiscus rosa-sinensis caused by Eggplant mottled dwarf virus in southern Italy. J. Phytopathol. 90:359-361.

Dijkstra, J., and de Jager, C. P. 1998. Virus transmission by grafting. Pages 116-124 in: Practical Plant virology: Protocols and Exercises. J. Dijkstra and C. P. de Jager, eds. Springer-Verlag, Berlin, Heidelberg, New York.

Green, S. K., Tsai, W. S., Shih, S. L., Black, L. L., Rezaian, A., Rashid, M. H., Roff, M. M. N., Myint, Y. Y., and Hong, L. T. A. 2001. Molecular characterization of begomoviruses associated with leafcurl diseases of tomato in Bangladesh, Laos, Malaysia, Myanmar, and Vietnam. Plant Dis. $85: 1286$.

Hanley-Bowdoin, L., Settlage, S. B., Orozco, B. M., Nagar, S., and Robertson, D. 1999. Geminiviruses: Models for plant DNA replication, transcription, and cell cycle regulation. Crit. Rev. Plant Sci. 18:71-106.

Huang, J. G., Fan, Z. F., Li, H. F., Tian, G. Z., and Hu, J. S. 2004. First report of Tomato mosaic virus on Hibiscus rosa-sinensis in China. Plant Dis. 88: 683

Inoue-Nagata, A. K., Albuquerque, L. C., Rocha, W. B., and Nagata, T. 2004. A simple method for cloning the complete begomovirus genome using the bacteriophage phi29 DNA polymerase. J. Virol. Methods 116:209-211.

Jan, F. J., Fagoaga, C., Pang, S. Z., and Gonsalves, D. 2000. A single chimeric transgene derived from two distinct viruses confers multi-virus resistance in transgenic plants through homology-dependent gene silencing. J. Gen. Virol. 81:2103-2109.

Kon, T., Rojas, M. R., Abdourhamane, I. K., and Gilbertson, R. L. 2009. Roles and interactions of begomoviruses and satellite DNAs associated with okra leaf curl disease in Mali, West Africa. J. Gen. Virol. 90:1001-1013.

Kumar, S., Stecher, G., Li, M., Knyaz, C., and Tamura, K. 2018. MEGA X Molecular evolutionary genetics analysis across computing platforms. Mol Biol. Evol. 35:1547-1549.

Letschert, B., Adam, G., Lesemann, D.-E., Willingmann, P., and Heinze, C. 2002 Detection and differentiation of serologically crossreacting tobamoviruses of economic importance by RT-PCR and RT-PCR-RFLP. J. Virol. Methods 106:1-10.

Li, J., and Zhou, X. P. 2010. First report of Kenaf leaf curl virus and Malvastrum yellow vein baoshan virus associated with yellow vein disease of Sidaacuta. J. Plant Pathol. 92:S113.

Li, S. C., and Chang, Y. C. 2002. First report of Hibiscus chlorotic ringspot virus in Taiwan. Plant Pathol. 51:803.

Mansoor, S., Briddon, R. W., Bull, S. E., Bedford, I. D., Bashir, A., Hussain, M., Saeed, M., Zafar, Y., Malik, K. A., Fauquet, C., and Markham, P. G. 2003. Cotton leaf curl disease is associated with multiple monopartite begomoviruses supported by single DNA-b. Arch. Virol. 148: 1969-1986.

Martin, D. P., Murrell, B., Golden, M., and Khoosal, A., and Muhire, B. 2015 RDP4: Detection and analysis of recombination patterns in virus genomes. Virus Evol. 1:1-5.

Melgarejo, T. A., Kon, T., and Gilbertson, R. L. 2015. Molecular and biological characterization of distinct strains of Jatropha mosaic virus from the Dominican Republic reveal a potential to infect crop plants. Phytopathology 105:141-153.

Muhire, B. M., Varsani, A., and Martin, D. P. 2014. SDT: A virus classification tool based on pairwise sequence alignment and identity calculation. PLoS One 9:e108277.

Napoli, C., Lemieux, C., and Jorgensen, R. 1990. Introduction of a chimeric chalcone synthase gene into petunia results in reversible co-suppression of homologous genes in trans. Plant Cell 2:279-289.

Paul, S., Ghosh, R., Chaudhuri, S., Ghosh, S. K., and Roy, A. 2009. Biological and molecular variability of the begomoviruses associated with leaf curl disease of Kenaf in India. J. Plant Pathol. 91:637-647.

Rajeshwari, R., Reddy, R. V. C., Maruthi, M. N., Colvin, J., Seal, S. E., and Muniyappa, V. 2005. Host range, vector relationships and sequence comparison of a begomovirus infecting hibiscus in India. Ann. Appl. Biol. 147:15-25.

Rojas, M., Gilbertson, R., and Maxwell, D. 1993. Use of degenerate primers in the polymerase chain reaction to detect whitefly-transmitted geminiviruses. Plant Dis. 77:340-347.

Ross, I. A. 2003. Hibiscus rosa-sinensis Pages. 253-266 in: Medicinal Plants of the World: Volume 1: Chemical Constituents, Traditional and Modern Medicinal Uses. Humana Press, Totowa, NJ, U.S.A.

Saeed, M. 2008. Limitations observed in the use of agroinoculation for geminivirus research. Virus Genes 37:434-435.

Srinivasan, K. G., Narendrakumar, R., and Wong, S. M. 2002. Hibiscus virus S is a new subgroup II tobamovirus: Evidence from its unique coat protein and movement protein sequences. Arch. Virol. 147:1585-1598. 
Srinivasan, K. G., and Wong, S. M. 2006. Cloning and characterization of a new tobamovirus infecting Hibiscus rosa-sinensis. Acta Hortic. 722:185-190.

Stenger, D. C., Revington, G. N., Stevenson, M. C., and Bisaro, D. M. 1991.

Replicational release of geminivirus genomes from tandemly repeated copies: Evidence for rolling-circle replication of a plant viral DNA. Proc. Natl. Acad. Sci. U.S.A. 88:8029-8033.

Stephan, D., Siddiqua, M., Ta Hoang, A., Engelmann, J., Winter, S., and Maiss, E. 2008. Complete nucleotide sequence and experimental host range of Okra mosaic virus. Virus Genes 36:231-240.

Tahir, M. N., and Mansoor, S. 2011. $\beta C 1$ of chili leaf curl betasatellite is a pathogenicity determinant. Virol. J. 8:509.

Thompson, J. D., Higgins, D. G., and Gibson, T. J. 1994. CLUSTAL W: Improving the sensitivity of progressive multiple sequence alignment through sequence weighting, position-specific gap penalties and weight matrix choice. Nucleic Acids Res. 22:4673-4680.

Waterworth, H. E. 1976. Purification and properties of Hibiscus chlorotic ringspot virus. Phytopathology 66:570-575.

Wu, C. Y., Lai, Y. C., Lin, N. S., Hsu, Y. H., Tsai, H. T., Liao, J. Y., and Hu, C. C. 2008. A simplified method of constructing infectious clones of begomovirus employing limited restriction enzyme digestion of products of rolling circle amplification. J. Virol. Methods 147:355-359.
Xie, Y., Wu, P., Liu, P., Gong, H., and Zhou, X. 2010. Characterization of alphasatellites associated with monopartite begomovirus/betasatellite complexes in Yunnan, China. Virol. J. 7:178-188.

Xu, J., De Barro, P. J., and Liu, S. S. 2010. Reproductive incompatibility among genetic groups of Bemisia tabaci supports the proposition that the whitefly is a cryptic species complex. Bull. Entomol. Res. 100:359-366.

Yang, J.-Y., Iwasaki, M., Machida, C., Machida, Y., Zhou, X., and Chua, N.-H. 2008 . $\beta C 1$, the pathogenicity factor of TYLCCV, interacts with AS1 to alter the leaf development and suppress selective jasmonic acid responses. Genes Dev. 22:2564-2577.

Yang, X., Guo, W., Ma, X., An, Q., and Zhou, X. 2011. Molecular characterization of Tomato leaf curl china virus, infecting tomato plants in China, and functional analyses of its associated betasatellite. Appl. Environ. Microbiol. 77 3092-3101

Zerbini, F. M., Briddon, R. W., Idris, A., Martin, D. P., Moriones, E., NavasCastillo, J., Rivera-Bustamante, R., Roumagnac, P., and Varsani, A., and ICTV Report Consortium. 2017. ICTV virus taxonomy profile: Geminiviridae. J. Gen. Virol. 98:131-133.

Zheng, Y. X., Huang, C. H., Cheng, Y. H., Kuo, F. Y., and Jan, F. J. 2010. First report of Tomato spotted wilt virus in sweet pepper in Taiwan. Plant Dis. 94 920 